\title{
The Utilization of Open Educational Resources in the Collaborative Learning Environment to Enhance the Critical Thinking Skill
}

\author{
Dwi Sulisworo (Corresponding author) \\ Physics Education Department, Ahmad Dahlan University \\ J1. Pramuka No. 42, Yogyakarta, Indonesia 55164 \\ Tel: +6281328387777Ｅ-mail: sulisworo@gmail.com \\ Fakhrunisyah Syarif \\ Physics Education Department, Ahmad Dahlan University \\ Jl. Pramuka No. 42, Yogyakarta, Indonesia 55164 \\ Tel: +62 85237362060 E-mail: fakhrunisyah@gmail.com
}

Received: January 1, 2018 Accepted: January 22, 2018 Published: January 29, 2018

doi:10.5296/ijld.v8i1.12399 URL: https://doi.org/10.5296/ijld.v8i1.12399

\begin{abstract}
Critical thinking as an outcome of learning is an essential issue in education. The application of the concept of Open Educational Resources or OER provides opportunities for students to obtain information more efficiently to support their learning. On the other hand, the collaborative learning is believed to be a robust pedagogical approach to build a good learning experience. This research describes and explores how the application of collaborative learning by using OER can enhance critical thinking skills. The method of this study was the pre-test and post-test one group design in physics lessons at secondary school students. Statistical analysis used paired t-test with an error of 5\%. The teacher can measure the critical thinking skill by giving essay test. Scoring considered the process undertaken in problem-solving. The results of this study showed an increase in critical thinking skills significantly. This study also further discusses the implications associated with this research on learning physics.
\end{abstract}

Keywords: critical thinking, collaborative learning, education, open educational resources, physics. 


\section{Introduction}

In the digital era nowadays, one can get information quickly and in a vast number of it. Therefore, the skill of selecting the critical and suitable information that meets the need becomes a necessity. The critical thinking skills will influence one in deciding the information. These skills become a problem in education since there is still a gap of student's ability in managing information well.

In another hand, the competency demand of current education is to have higher order thinking skills which one of them is critical thinking skill. Learning orientation in Indonesia that still focuses on teacher-centered learning has made the student's opportunities in enhancing critical thinking becomes not maximal. The government policy of Indonesia to implement a more flexible curriculum with student-centered learning becomes an opportunity for a better learning system development for students in enhancing critical thinking skills.

Educators believe that collaborative learning is a pedagogically excellent learning approach to creating a learning environment that encourages critical thinking skills. Considering the ease of getting learning sources (which is well known as open educational resources) through mobile technology now, teachers can develop a collaborative learning by the student's need in the digital era. This research aims to explore the impacts of collaborative learning supported by open educational resources towards critical thinking skills at secondary school students.

\section{Theoretical Background}

\subsection{Open Educational Resources}

Education and technology in the history have a tight relation. To build a good learning environment, it's not enough by only utilizing the newest technology (Sulisworo, 2016). School is not just introducing the latest technology to students. The most important thing is how to integrate technology as a tool to support the learning process so that students can achieve their competencies better. The role of the teacher in this integration process becomes very important for the success of learning process (Algers \& Silva-Fletcher, 2015, Atenas et al., 2015; Harsasi, 2015; Islim et al., 2016).

Technology penetration especially ICT through smartphones is relatively high year by year. Through this technology, students can access vast unlimited information. This technique becomes an opportunity for teachers to improve the learning process (Guo et al., 2015; Islim \& Cagiltay, 2016; Kaendler et al., 2015; Newhouse, 2015). Now, there are numerous learning sources to obtain to support the learning process in achieving specific competencies (Islim et al., 2016; Krajcso, 2016; Piedra et al., 2015). Educators need to consider the necessity and the comfort of using this technology in managing the learning process in the new perspective using those learning sources (Harsasi, 2015; Islim et al., 2016; Obradović et al., 2016).

The availability of online learning sources which can be accessed by all people creates the concept of open educational resources. Open Educational Resources (OERs) are any instructional materials that are in the public domain or introduced with a free license (Dutta, 2016; Islim et al., 2016; Piedra et al., 2015). The nature of these friendly materials means that 
anyone can legally and freely copy, use, adapt and re-share them. OERs range from textbooks to curricula, syllabi, lecture notes, assignments, tests, projects, audio, video and animation (Johnstone, 2005). OER is believed to be able to accelerate the human development globally. Various researchers are conducted to improve the learning effectiveness by utilizing OER both from the teacher and students sides in multiple aspects such as belief, motivation, learning result, and thinking skills. The researchers result sustainably contributes to the policy and strategy for better OER management (Guo et al., 2015; Obradović et al., 2016; Piedra et al., 2015).

\subsection{Collaborative Learning}

In the uncertain and complex world nowadays, it's not enough if the students only rely on understanding in using tools to collect information (Newhouse, 2015; Sulisworo \& Toifur, 2016; Tabuenca et al., 2014). They need skills of creativity and the solving problem (Dwyer et al., 2014; Griffin \& Care, 2014; Shiraev et al., 2016). As a consequence, critical and creative thinking skills, the knowledge analyzing and synthesizing abilities to solve technical, social, economic and other issues become important. Anticipating the change of global environment, the educators currently see that collaborative learning gives a lot of advantages for students (Blasco-Arcas et al., 2013; Halili et al., 2015; Lee et al., 2014; O'Sullivan, 2017). This technique is primarily related to edges on other aspects except for new knowledge acquisition, but more on social skills element (Gilboy et al., 2015; Hämäläinen \& Laine, 2014; Ku et al., 2013; Zheng et al., 2014).

Collaborative learning is fundamentally a learning that emphasizes on building learning communities (Halili et al., 2015; Ku et al., 2013; Zheng et al., 2014). The teacher can build the learning communities through forming groups from various backgrounds of students to achieve the agreed learning goals together. Through this collaborative learning, students can share knowledge and learning sources each other. In the collaborative learning environment, students can do activities by utilizing learning sources. Skills in finding and managing the massive number of information from the internet will influence the group's performance in achieving the learning goals (Hämäläinen \& Laine, 2014; Ku et al., 2013; O'Sullivan, 2017). In collaborative learning, every group member needs creating shared meaning and a shared commitment with other members to complete an organized group.

\subsection{Critical Thinking}

In knowledge, higher-order thinking skills development including critical thinking skills is significant (Dwyer et al., 2014; Griffin \& Care, 2014). Education is not only mastering knowledge but also including the expertise to integrate the experience to be a new and more meaningful thing (Algers \& Silva-Fletcher, 2015; Guo et al., 2015; Obradović et al., 2016). The teacher can assemble problem-solving activities to enhance critical thinking (Howard et al., 2015; McPeck, 2016). Also, the teacher can combine this strategy with promoting the complex problem-solving (Howard et al., 2015; Wallace \& Jefferson, 2015). Complex problems are problems which someone can't indirectly solve with one procedure or particular perspective, but they need higher order thinking skills to find and combine various facts to get problem-solving (Carter et al., 2014; Shiraev et al., 2016). 
Critical thinking is a multidimensional construct. In learning, critical thinking skills can be viewed on how to use various concepts combination, formula, principles, and rules to solve complex problems (McPeck, 2016). Based on the dimension, knowledge consists of factual, conceptual, procedural, and metacognitive. By considering the nature of each knowledge dimension, in the process of measuring critical thinking skills, a contextual problem or test question which is not artificial can be developed. To solve it, it needs skills to combine concepts, formula, principles, and rules which meet the learning goals (Howard et al., 2015; Pitt et al., 2015; Wallace \& Jefferson, 2015).

During the collaborative learning, the groups are facing various complex problems. The teams can identify multiple ways to be able to solve the problems. Through the team regulating mechanism they agreed on, every group member can contribute to solving problems by building shared meaning and shared information they have (Flood, 2015; Kong, 2014). Interaction in this process of problem-solving together will enhance critical thinking skills both individually and in a group (Alotaibi, 2013; Hämäläinen \& Laine, 2014; Huber \& Kuncel, 2016; Ku et al., 2013).

\section{Methods}

This research is a quantitative research with the quasi-experimental approach. The research design is pre-test and post-test one group design. The independent variable of the study is collaborative learning strategy using open educational resources in student's learning activities. The dependent variable is critical thinking skill measured before and after the learning process. The learning process was conducted for three weeks. The learning activities are in one of the classes at a secondary school in Bima, West Nusa Tenggara, Indonesia. The number of respondents was 26 students from the same level. The researcher arranged this study for three months (from January to March 2017) including from preparation for learning data collection activities.

To support learning, teachers prepared lesson plans with problem-based learning approach. The stages of the learning activities were as the following stages:

a. In the early stage, the teacher explained a particular phenomenon and presented a problem. In describing the event, the teacher used a real phenomenon. Then, the teacher stimulated a discussion to find out various issues related to the aspect. After students found the problems, the class was able to design the next learning activities.

b. In the process of problem solving, every group can discuss to find the solution based on the knowledge they have. On the aspects they haven't understood, students can make a list of what they need to know further. The list of knowledge or information they will find further will become targets of group learning.

c. Next, the groups shared tasks with the members to find relevant information to solve the problems. In this stage, all students can use their smartphone to search for pertinent information to the problem. Here, each member could share with other or find by $\mathrm{him} /$ herself how to solve the problem. In this stage, Student used OER by searching online information. Then, the student explained and learned the un-understood knowledge 
using OER. After finishing these learning targets, all groups presented their learning result by telling how the problems can be solved well.

Critical thinking was measured by giving eight essay questions including questions with cognitive domain level of $\mathrm{C} 4$ or $\mathrm{C} 5$. The score of every item was provided under the stages of problem-solving with the maximal score of 4 . If the students can solve the questions of critical thinking skill, the total score was 28 ( 7 questions with the maximal score of 4 each).

\section{Result and Discussion}

In this research, data processed were pre-test and post-test data related to critical thinking skills. Table 1 shows the descriptive statistic of the data.

Table 1 shows that mean of critical thinking skills of post-test (14.46) is higher than mean of pretest (9.23). To find out the significance of the mean difference, it needs difference (comparative) test. One of difference) test requirements is normality test. Figure 1 expresses the frequency graphic of critical thinking skills before and after learning.

Table 1. Descriptive statistics

\begin{tabular}{rrr}
\hline Statistic & Pre-Test & Post-Test \\
$\mathrm{N}$ & 26.00 & 26.00 \\
Mean & 9.2308 & 14.4615 \\
Median & 9.0000 & 14.5000 \\
\hline Variance & 2.265 & 2.178 \\
Std. Deviation & 1.50486 & 1.47596 \\
\hline Minimum & 7.00 & 12.00 \\
Maximum & 12.00 & 17.00 \\
\hline Range & 5.00 & 5.00 \\
Skewness & .108 & -.080 \\
Kurtosis & -.818 & -.822 \\
\hline
\end{tabular}

The histogram (Figure 1) describes the tendency that the data is not a normal distribution. It also relates to the number of samples that are relatively small. Table 2 shows the data processing result for normality test with Kolmogorov-Smirnov and Shapiro-Wilk test. 

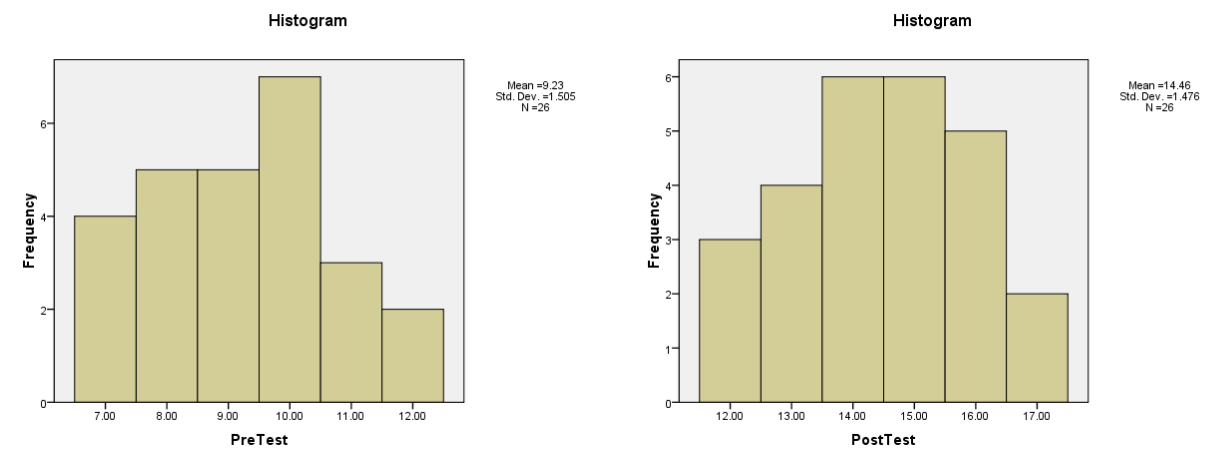

Figure 1. Histogram of pre-test and post-test

Table 2 shows that the data of critical thinking skills before and after learning is not a normal distribution for margin error of 5\%. At pretest, significant limit is on the level of 0.099 for Kolmogorov-Smirnov test or 0.096 for Shapiro-Wilk test. At posttest, the significant level is at the level of 0.187 for Kolmogorov-Smirnov or 0.139 for Shapiro-Wilk test. Based on the result of the normality analysis test, researcher processed the data using the non-parametric technique with Sign Test to find the difference test of means. Table 3 shows the result.

Table 2. Tests of Normality

\begin{tabular}{rcccccc}
\hline & \multicolumn{3}{c}{ Kolmogorov-Smirnov $^{\mathrm{a}}$} & \multicolumn{3}{c}{ Shapiro-Wilk } \\
\hline & Statistic & df & Sig. & Statistic & df & Sig. \\
\hline Pre-Test & .157 & 26 & .099 & .934 & 26 & .096 \\
Post-Test & .142 & 26 & .187 & .941 & 26 & .139 \\
\hline
\end{tabular}

a. Lilliefors Significance Correction

From Table 3 (on the part of test statistics) it can be seen that on the margin error of $5 \%$, there is a significant difference of mean between posttest and pretest result. Although this finding shows the increase of critical thinking skills (from the mean of 9.23 before learning to 14.46 after learning), this value is not good enough if compared to the maximal score of 28 . It means even though collaborative learning strategy has been applied by using OER, critical thinking skills of the students have not achieved the expected standard. In another side, the result of statistical analysis convincingly shows the significant increase. This result implies the need for more in-depth analysis as the reflection to know the aspects which need to improve to make a better learning process.

This research is more suitable to be called as a classroom action research where collaborative learning strategy with OER was applied to enhance student's critical thinking skills. As an action research, there was a lack of subject schedule and materials used. The impact of this 


\section{Macrothink}

International Journal of Learning and Development

ISSN 2164-4063 2018, Vol. 8, No. 1

decrease was on the level of sample readiness where teacher and students were not expert to apply this learning strategy. The highest test score could be obtained in the following cycle in applying learning strategy.The significant increase in the result becomes an excellent opportunity for sustainable learning improvement efforts. Many researchers have taken this benefit of this learning strategy (Han et al., 2015; Halili et al., 2015; Krajcso, 2016).

Table 3. Sign Test Result

Frequencies

PostTest - PreTest

Negative Differences ${ }^{\mathrm{a}}$

Positive Differences ${ }^{b}$

Ties $^{\mathrm{c}}$

Total 26
a. Post-Test $<$ Pre-Test
b. Post-Test $>$ Pre-Test
c. Post-Test $=$ Pre-Test

\begin{tabular}{cr}
\hline & Test Statistics $^{\text {a }}$ \\
\hline \multicolumn{2}{c}{ Post-Test - Pre-Test } \\
\hline$Z$ & -4.903 \\
Asymp. Sig. (2-tailed) & .000 \\
\hline
\end{tabular}

a. Sign Test

The optimistic side of this research was that high ICT literacy of young Indonesian generation including in the rural area could be an opportunity for the improvement of learning quality especially related to critical thinking skills. Several factors causing the significant enhancement of critical thinking skills were high student's enthusiasm and appreciation towards this learning strategy. This finding is relatively same to the other research in many areas (Lee et al., 2014; Piedra et al., 2015). So far, there is a tendency that learning at schools less utilizes ICT including by using OER from the internet. In opposite, in the daily life students have been accustomed to and comfortable with the use of smartphones for various activities (Flood, 2015; Kong, 2014; Sulisworo \& Toifur, 2016). Given a chance to use smartphones for searching information related to their learning, this will create a better learning enthusiasm level (Gilboy et al., 2015; Kong, 2014). Collaborative learning strategy applied enables the student's social skills to develop, moreover the interaction level on learning in the process of sharing information and construing new knowledge (Alotaibi, 2013; Hämäläinen \& Laine, 2014, 2015; O'Sullivan, 2017). Student-centered learning strategy gives an opportunity for students to design more various and flexible group activities in achieving learning goals. This explanation also becomes another reason for developing student's critical 
thinking skills in the rural area.

\section{Conclusion}

To anticipate the global change in the education system that encourages higher order thinking skills development where critical thinking skills are one of them, the government of Indonesia has applied a more flexible curriculum by making students as the center of learning. The excellent level of IT literacy of students in the rural area is an opportunity to use OER in education. Learning strategy application with OER in collaborative learning at secondary school in the rural area can significantly develop the critical thinking skills. Several factors which support the success of the strategy application are student's enthusiasm and appreciation on collaborative learning strategy and also the use of technology to get comprehensive and deeper learning sources. Through the learning strategy, students can share new information and meaning with other students, so it enables the critical thinking skills to enhance together.

\section{Acknowledgement}

The research is funded by Research and Development Bureau of Ahmad Dahlan University No. PHB-058/SP3/LPP-UAD/IV/2017.

\section{References}

Algers, A. \& Silva-Fletcher, A. (2015) Teachers' Perceived Value, Motivations for and Adoption of Open Educational Resources in Animal and Food Sciences. International Journal of Emerging Technologies in Learning (iJET), 10(2), 35-45. http://dx.doi.org/10.3991/ijet.v10i2.4427

Alotaibi, K. N. (2013). The effects of blended learning on developing critical thinking skills. Education Journal, 2(4), 176-185. http://dx/doi.org/10.11648/j.edu.20130204.21

Atenas, J., Havemann, L., \& Priego, E. (2015). Open Data as Open Educational Resources: Towards transversal skills and global citizenship, Open Praxis, 7(4), 377-389. http://dx.doi.org/10.5944/openpraxis.7.4.233

Blasco-Arcas, L., Buil, I., Hernández-Ortega, B., \& Sese, F. J. (2013). Using clickers in class. The role of interactivity, active collaborative learning and engagement in learning $\begin{array}{lllll}\text { performance. Computers } \quad \& \quad \text { Education, } & \text { 62, }\end{array}$ https://doi.org/10.1016/j.compedu.2012.10.019

Carter, A. G., Sidebotham, M., Creedy, D. K., Fenwick, J., \& Gamble, J. (2014). Using root cause analysis to promote critical thinking in final year Bachelor of Midwifery students. Nurse education today, 34(6), 1018-1023. http://dx.doi.org/10.1016/j.nedt.2013.10.020

Dutta, I. (2016). Open Educational Resources (OER): Opportunities and Challenges for Indian Higher Education. Turkish Online Journal of Distance Education-TOJDE, 17(2), 110-121.

Dwyer, C. P., Hogan, M. J., \& Stewart, I. (2014). An integrated critical thinking framework 
for the 21st century. Thinking Skills and Creativity, 12, 43-52. https://doi.org/10.1016/j.tsc.2013.12.004

Flood, P. A. (2015). Critical thinking skills and information literacy skills: Discerning online information among high school students. Liberty University.

Gilboy, M. B., Heinerichs, S., \& Pazzaglia, G. (2015). Enhancing student engagement using the flipped classroom. Journal of nutrition education and behavior, 47(1), 109-114. https://doi.org/10.1016/j.jneb.2014.08.008

Griffin, P., \& Care, E. (Eds.). (2014). Assessment and teaching of 21st century skills: Methods and approach. Springer.

Guo, Y., Zhang, M., Bonk, C. J., \& Li, Y. (2015). Chinese Faculty Members' Open Educational Resources (OER) Usage Status and the Barriers to OER Development and Usage. International Journal of Emerging Technologies in Learning (iJET), 10(5), 59-65. http://dx.doi.org/10.3991/ijet.v10i5.4819

Hämäläinen, R., \& Laine, K. (2014). Classroom orchestration: Balancing between personal and collaborative learning processes. International Journal of Virtual and Personal Learning Environments (IJVPLE), 5(3), 33-50. http://dx.doi.org/10.4018/IJVPLE.2014070103

Han, S., Capraro, R., \& Capraro, M. M. (2015). How science, technology, engineering, and mathematics (STEM) project-based learning (PBL) affects high, middle, and low achievers differently: The impact of student factors on achievement. International Journal of Science and Mathematics Education, 13(5), 1089-1113. http://dx.doi.org/10.1007/s10763-014-9526-0

Halili, S. H., Razak, R. A., \& Zainuddin, Z. (2015). Enhancing Collaborative Learning in Flipped Classroom. Australian Journal of Basic and Applied Sciences, 9(7), 147-149.

Harsasi, M. (2015). The use of open educational resources in online learning: A Study of Students' Perception. Turkish Online Journal of Distance Education-TOJDE, 16(3), 74-87.

Howard, L. W., Tang, T. L. P., \& Austin, M. J. (2015). Teaching critical thinking skills: Ability, motivation, intervention, and the Pygmalion effect. Journal of Business Ethics, 128(1), 133-147. https://doi.org/10.1007/s10551-014-2084-0

Huber, C. R., \& Kuncel, N. R. (2016). Does college teach critical thinking? A meta-analysis. Review of Educational Research, 86(2), 431-468. https://doi.org/10.3102/0034654315605917

Islim, O. F., Koybasi, N. A. G., \& Cagiltay, K. (2016). Use of Open Educational Resources: How, Why and Why Not?. Executive Editor, 28(2), 230-240.

Islim, O. F., \& Cagiltay, K. (2016). The Impact of OER on Instructional Effectiveness: A Case Study. Eurasia Journal of Mathematics, Science \& Technology Education, 12(3), 559-567. https://doi.org/10.12973/iser.2016.2003a

Johnstone, S. M. (2005). Open educational resources serve the world. Educause Quarterly, 28(3), 15-18. 
Kaendler, C., Wiedmann, M., Rummel, N., \& Spada, H. (2015). Teacher competencies for the implementation of collaborative learning in the classroom: A framework and research review. Educational Psychology Review, 27(3), 505-536. https://doi.org/10.1007/s10648-014-9288-9

Kim, K., Sharma, P., Land, S. M., \& Furlong, K. P. (2013). Effects of active learning on enhancing student critical thinking in an undergraduate general science course. Innovative Higher Education, 38(3), 223-235. https://doi.org/10.1007/s10755-012-9236-X

Kong, S. C. (2014). Developing information literacy and critical thinking skills through domain knowledge learning in digital classrooms: An experience of practicing flipped classroom strategy. Computers \& Education, 78, 160-173. https://doi.org/10.1016/j.compedu.2014.05.009

Ku, H. Y., Tseng, H. W., \& Akarasriworn, C. (2013). Collaboration factors, teamwork satisfaction, and student attitudes toward online collaborative learning. Computers in Human Behavior, 29(3), 922-929. https://doi.org/10.1016/j.chb.2012.12.019

Krajcso, Z. (2016). Classification and quality criteria for Open Educational Resources in the field of foreign language learning. Journal of Language and Cultural Education, 4(1), 48-59. https://doi.org/10.1515/jolace-2016-0004

Lee, K., Tsai, P. S., Chai, C. S., \& Koh, J. H. L. (2014). Students' perceptions of self directed learning and collaborative learning with and without technology. Journal of Computer Assisted Learning, 30(5), 425-437. http://dx.doi.org:/10.1111/jcal.12055

McPeck, J. E. (2016). Teaching critical thinking: Dialogue and dialectic. Routledge.

Newhouse, C. P. (2015). Measuring the meaningful use of ICT in schools: a learning environments attributes approach. International Journal of Technology Enhanced Learning (IJTEL), 7(4), 309-325. https://doi.org/10.1504/IJTEL.2015.074187

Obradović, I., Stanković, R., Kitanović, O., \& Vorkapić, D. (2016). Building learning capacity by blending different sources of knowledge. International Journal of Learning and Intellectual Capital, 13(2-3), 135-148. https://doi.org/10.1504/IJLIC.2016.075698

O'Sullivan, D., Krewer, F., Frankl, G. (2017). Technology enhanced collaborative learning using a project-based learning management system. International Journal of Technology Enhanced Learning (IJTEL), 9(1), 14-36. https://doi.org/10.1504/IJTEL.2017.084085

Piedra, N., Chicaiza, J., López, J., \& Tovar, E. (2015). Seeking Open Educational Resources to Compose Massive Open Online Courses in Engineering Education An Approach based on Linked Open Data. Journal of Universal Computer Science, 21(5), 679-711.

Pitt, V., Powis, D., Levett-Jones, T., \& Hunter, S. (2015). The influence of critical thinking skills on performance and progression in a pre-registration nursing program. Nurse education today, 35(1), 125-131. https://doi.org/10.1016/j.nedt.2014.08.006

Shiraev, E. B., Shiraev, E. B., \& Levy, D. A. (2016). Cross-cultural psychology: Critical thinking and contemporary applications. Taylor \& Francis. 


\section{Macrothink}

International Journal of Learning and Development

ISSN 2164-4063 2018, Vol. 8, No. 1

Sulisworo, D. (2016). The Contribution of the Education System Quality to Improve the Nation's Competitiveness of Indonesia. Journal of Education and Learning (EduLearn), 10(2), 127-138. http://dx.doi.org/10.11591/edulearn.v10i2.3468

Sulisworo, D., \& Toifur, M. (2016). The role of mobile learning on the learning environment shifting at high school in Indonesia. International Journal of Mobile Learning and Organisation, 10(3), 159-170. https://doi.org/10.1504/IJMLO.2016.077864

Tabuenca, B., Kalz, M., Ternier, S., \& Specht, M. (2014). Mobile authoring of open educational resources for authentic learning scenarios. Universal Access in the Information Society, 1-15.

Wallace, E. D., \& Jefferson, R. N. (2015). Developing critical thinking skills: Assessing the effectiveness of workbook exercises. Journal of College Teaching \& Learning (Online), $12(2), 101$.

Zheng, L., Yang, J., Cheng, W., \& Huang, R. (2014). Emerging approaches for supporting easy, engaged and effective collaborative learning. Journal of King Saud University-Computer and Information Sciences, 26(1), 11-16. http://dx.doi.org/10.1016/j.jksuci.2013.10.002

\section{Copyright Disclaimer}

Copyright for this article is retained by the author(s), with first publication rights granted to the journal.

This is an open-access article distributed under the terms and conditions of the Creative Commons Attribution license (http://creativecommons.org/licenses/by/4.0/). 